\begin{tabular}{|c|c|c|}
\hline & $\begin{array}{l}\text { ANNALES INSTITUTI SLAVICI } \\
\text { UNIVERSITATIS DEBRECENIENSIS }\end{array}$ & \\
\hline SLAVICA XLVIII & 2019 & DEBRECEN \\
\hline
\end{tabular}

\author{
Наталия НикОЛиНА - Зоя ПЕТРОВА
}

\title{
СИСТЕМА КОМПАРАТИВНЫХ ТРОПОВ В РОМАНЕ Е. ВОДОЛАЗКИНА «АВИАТОР»
}

\section{The System of Comparative Tropes in «Aviator», a Novel by E. Vodolazkin}

\begin{abstract}
The article discusses the functioning of metaphors and similes in the text of E. Vodolazkin's novel «Aviator». The tropes are divided into two groups: conceptualizing tropes and non-plot-forming ones. The main semantic types of comparative tropes are noted as proceeding from «tenors» and «vehicles» of metaphors and similes. It is shown that the tropes interact with each other and form a system in the text. Emphasis is put on the dynamism of metaphors and similes in the novel: they regularly reflect the hero's changing perceptions. Comparative tropes play an important role in the unfolding of the key motifs of the novel and are associated with its various temporal and narrative plans.
\end{abstract}

Keywords: metaphor, simile, comparative trope, semantic class, system of tropes, motif, «tenor», «vehicle»

Функционирование компаративных тропов (метафор и сравнений) в художественной прозе давно привлекало к себе внимание исследователей: изучалась метафорика в различных идиостилях, например Н. В. Гоголя [КОЖЕВНиковА 2009: 663-672], Ф. М. Достоевского [РужицКИй 2015], А. П. Чехова [КОЖЕВНИКОВА 2011: 284-317], В. В. Набокова [ГУСЕВА 2018], Е. Замятина [КОЖЕВНИКОВА 2009: 743-752], А. П. Платонова [КОЖЕВНИковА 2009: 753-762], О. Э. Мандельштама [МЕЛЬнИкОВА 2003], А. Грина [КлЮчЕРОВА 2017] и др., тропы в рамках определенного литературного направления [ЛЕЭМЕТС 1974], связь тропов и реалий, повтор и варьирование тропов, однако до сих пор относительно мало работ, посвященных описанию компаративных тропов на материале конкретных произведений [БАРАНОВ - электронный ресурс; ГОЛОВНЕВА-НОВИКОВА 2018; ДМИТРОВСКАЯ 2001, КАДИМОВ-МАЛЛАЛИЕВ 2009; ОГОЛЬЦЕВА 2010]. Задача нашей статьи - рассмотреть особенности употребления метафор и сравнений в романе современного прозаика Е. Водолазкина «Авиатор» (2016 г.).

Компаративные тропы в романе «Авиатор» можно разделить на два типа. Первый тип тропов можно условно назвать концептуализирующими, они

Работа выполнена при поддержке гранта РФФИ 19-512-23004 «Метафорическая картина мира современной русской и венгерской прозы конца XX - начала XXI в. (сопоставительный анализ)». 
непосредственно связаны с развитием сюжета романа и, соответственно, с его идейно-эстетическим содержанием. Эти тропы в романе прежде всего определяют образ главного героя, характеризуют и оценивают его. Одновременно они служат источником порождения разветвленных образных параллелей в тексте. Основная метафора этой группы вынесена в заглавие - «Авиатор». Заглавие авиатор связывает разные временные планы произведения, при этом это слово не сразу метафоризируется. Впервые оно употребляется в прямом значении в воспоминаниях о раннем детстве, но уже содержит потенцию для семантического сдвига: «Мы с кузеном Севой на Финском заливе. <..> Воображаем себя авиаторами. Летим вдвоем: на переднем сиденье я, на заднем Сева. Там, в холодном небе, пустынно и одиноко, но нас согревает наша дружба.

- Авиатор Платонов, - кричит мне сзади Сева.- Авиатор Платонов, по курсу населенный пункт Куоккала! Я не понимаю, зачем Сева обращается к своему коллеге так церемонно. Может быть, для того, чтобы Платонов не забывал, что он авиатор» [ВодОЛАЗКИН 2019: 24].

По мере развития сюжета семантика слова усложняется. Следующее его употребление связано с описанием полетов аэропланов: «Меня завораживало само слово - авиатор. Его звучание соединяло в себе красоту полета и рев мотора, свободу и мощь. Это было прекрасное слово. Позднее появился “летчик”, которого будто бы придумал Хлебников. Слово неплохое, но какое-то куцее: есть в нем что-то от воробья. А авиатор - это большая красивая птица. Такой птицей хотел быть и я. Авиатор Платонов. Это стало не то чтобы домашним именем, но время от времени меня так называли. И мне это нравилось» [ВодоЛАЗКИН 2019: 92]. Контекст, в котором употребляется это слово, содержит метаязыковой комментарий, образную параллель и наблюдения героя над звуковым обликом лексической единицы, участвующим в создании ее образного смысла.

Далее метафора авиатор служит основой для развития обобщающей образной параллели «жизнь - полет», которая конкретизируется в частной образной параллели «взлет авиатора - символ надлежащего течения жизни»: «Однажды в Сиверской я видел, как с плохо выкошенного поля взлетал аэроплан. Набирая разбег, авиатор объезжал выбоины, подпрыгивал на кочках и внезапно - о, радость! - оказался в воздухе. Глядя, как судорожно перемещается по полю машина, никто полета, откровенно говоря, не ожидал. А авиатор взлетел. $<\ldots>$ С каких-то пор эта картинка видится мне символом надлежащего течения жизни. Мне кажется, что у людей состоявшихся есть особенность: они мало зависят от окружающих. Независимость, конечно, не цель, но она - то, что помогает достигать цели. Вот бежишь ты по жизни со слабой надеждой взлететь, и все смотрят на тебя с жалостью, в лучшем случае - с непониманием. Но ты - взлетаешь, и все они с высоты кажутся точками. $<\ldots>$ А ты летишь в избранном тобой направлении и чертишь в эфире дорогие тебе фигуры. Стоящие внизу ими восхищаются (немножко, может быть, завидуют), но не в силах что-либо изменить, поскольку в этих сферах всё зависит лишь от умения летящего. От прекрасного в своем одиночестве авиатора» [ВодолАзКин 2019: 345]. 
В метафоре в этом контексте, таким образом, актуализируются такие смыслы, как независимость, одиночество, отстраненность. Она определяет основу сопоставления героя с «авиатором» - наличие широкого обзора мира сверху. Эта пространственная точка зрения мотивирует основное предназначение «авиатора» - дать описание ситуаций прошлого с мельчайшими присущими им деталями и воссоздать общую картину эпохи, см. слова Насти о Платонове: «как подробно он описывает всяческие детали, и чем старше они - тем с большей любовью! < . .> пишет проект грядущего всеобщего восстановления мира» [ВодоЛАЗКИН 2019: 277].

Инструментом фиксации прошлого, ушедшего «с поверхности Земли» мира является память. Почти весь текст романа - повествование от лица Платонова представляет собой ретроспекцию как результат ее действия. С точки зрения главного героя, именно то, что сохраняется в памяти, останется в реальном мире: «А может, всё где-то и останется - в какой-то части мирозданья, не обязательно ведь в моей голове - найдет себе безветренную гавань и будет в ней существовать» [ВодоЛАЗКин 2019: 186]. Память в романе концептуализируется, при этом в тексте используются разные образы памяти, которые дифференцируются на память спасающую и память убивающую. Прошлое для героя соответственно делится на два временных отрезка, между которыми - «разлом», «бездна». Память о первом прошлом (детстве) спасает, о втором - убивает: «Я видел вещи, которые выжигали меня изнутри, они не помещаются в слова. $<\ldots>$ Я это видел. И с тех пор безуспешно гоню из памяти» [ВодОЛАЗКИН 2019: 251].

Ключевое для романа понятие «память» характеризуется в тексте разными метафорами и сравнениями: зарастание памяти: «<..> трава - это зарастание памяти о человеке, <..> пока есть кому с этой травою справляться, человек каким-то образом на земле еще присутствует» [ВодолАзКИН 2019: 80], запечатление в памяти - фотография: «На лестничной площадке я обернулся и бросил взгляд на светлый прямоугольник двери. За спинами конвоя я увидел моих дорогих - оказалось, в последний раз. Я вижу их и сейчас с фотографuческой точностью. Знаю, что так же они увидели и меня обернувшегося. На всю жизнь сфотографировали - меня освещала вспышка их горя. После моей смерти две фотокарточки сольются в одну» [ВОДОЛАЗКИН 2019: 122-123], воспоминание - обратная съемка: «Вот показывается траурная процессия и в который, кажется, раз проезжает мимо нас. Я так жадно в нее всматриваюсь и так часто впоследствии прокручиваю это зрелище в памяти, что в моем сознании оно остается многократным. Будто в обратной съемке, процессия спешно возвращается к началу Невского <...>» [ВОДолАЗкин 2019: 317], воспоминание - фонарь в тумане: «Эта картинка мерцала в моей памяти размытым пятном, эдаким фонарем в тумане, а тут вдруг предстала во всей резкости» [ВОДОЛАЗКИН 2019: 393].

Устойчивое метафорическое обозначение главного героя - авиатор - дополняется в тексте другими его образными номинациями. Так, герой отождествляет себя с Лазарем, с этим евангельским образом связан мотив воскре- 
шения. Это и реальное воскрешение замороженного персонажа, и метафорическое воскрешение поколения, ср.: «Засыпая, я думал о Лазаре. Его судьба была для меня единственной надеждой. Если оказалось возможным воскресить четырехдневного мертвеца, от которого уже исходил смрад, что может быть невозможного в воскрешении замороженного по всем правилам человека?», «Думая сейчас о моей разморозке, я - ввиду количества ушедших лет - спрашиваю себя: не стала ли она воскрешением целого поколения? Ведь любая деталь, которую я сейчас припоминаю, автоматически становится деталью эпохи» [ВОДОЛАЗКИН 2019: 279].

Слово Лазарь имеет в тексте романа двойной смысл: с одной стороны, это отсылка к библейскому образу, с другой - лагерная аббревиатура: «- “ЛАЗАРЬ" - сокращение лазарета? - Это другое сокращение. < .. > “ “Лаборатория по замораживанию и регенерации"» [ВОДоЛАЗКИН 2019: 207].

Другой сквозной образ, связывающий разные временные планы романа, Робинзон Крузо, герой любимой, «целебной» детской книги, о которой Платонов неоднократно вспоминает в своем повествовании. Он сближает себя с Робинзоном на основе отношения ко времени, в результате в тексте отражается параллелизм судеб Платонова и литературного героя. Как и Робинзон, Платонов оказывается в другом времени: «Родивщее его время [Робинзона] осталось где-то далеко, может быть, даже уило навсегда. Он теперь в другом времени - с прежним опытом, прежними привычками, ему нужно либо их забыть, либо воссоздать весь утраченный мир, что очень непросто» [ВодОЛАЗКИн 2019: 42].

Параллельно обогащается дополнительными смыслами слово остров, в тексте сближаются необитаемый остров Робинзона и Соловки. Эта образная параллель далее развивается, при этом осмысливается сходство целей Платонова и Робинзона: «Я представлял себе Робинзона Крузо бредущим вдоль полосы прибоя, переносился на его остров со своего и, если даже не менялся с ним местами (зачем ему мой остров?), то сменял его на несколько мгновений в той благословенной необитаемой земле. $<\ldots>$ Те, что создали соловецкий ад, лишили людей человеческого, а Робинзон - он ведь, наоборот, очеловечил всю окружавшую его природу, сделал ее продолжением себя. Они разрушали всякую память о цивилизации, а он из ничего цивилизацию создавал. По памяти» [ВодолАзКин 2019: 192]. Как Робинзон, авиатор Платонов ставит себе задачу воскрешения поколения, тоже по памяти.

В дальнейшем имя Робинзон Крузо употребляется в тексте уже как метафора: «В моей прежней квартире я иногда чувствую себя будто на острове среди моря чужой жизни. Бедный Робинзон Крузо» [ВоДОЛАЗКин 2019: 290].

Эта метафора поддерживается другими конструкциями параллелизма: «я подумал: Робинзон за грехи был заброшен на остров и лишен своего родного пространства. А я лишился своего родного времени - и тоже ведь за грехи» [ВодОЛАЗКИН 2019: 297].

Сквозной образ Робинзон Крузо связан с детством героя, которое оценивается как рай, в противовес аду - лагерю: «<...> лагерь - aд не столько из-за телесных мучений, сколько из-за расчеловечивания многих, туда попавших. 
Чтобы не позволить истребить в себе остатки человеческого, нужно этот ад хоть на время покидать - хотя бы мысленно. Думать о Рae. $<\ldots>$

Проснешься, бывало, на даче рано утром - все спят еще. < .. > Тихо, как в Раю. Мне почему-то кажется, что в Раю должно быть тихо» [ВодолАзКин 2019: 163].

Образ рая взаимодействует в воспоминаниях о детстве с другими образами, которые сопровождаются высокой оценкой. Это образы гармонии и симметрии, присущих как любимому городу детства, так и семье: «Я ведь любил Петербург бесконечно. <..> Его гармония противостояла в моих глазах хаосу, который пугал и расстраивал меня с детства. <..> Ах, да - гармония. Строгость. Вот мы с отцом и матерью - я в центре, они по бокам, держат меня за руки, идем по Театральной улице от Фонтанки к Александринскому театру, прямо посередине улицы. Сами - воплощение симметрии, если угодно - гармонии» [ВОДОЛАЗКИН 2019: 31].

С детством героя связан в романе мотив утраченного рая. Характерно, что в детских воспоминаниях присутствуют возвышенные библейские образы ангел Апокалипсиса; колесниия, несущая огнебориев; ковчег, см. например: «А еще вспомнился пожар. Не сам пожар, а как ехали его тушить по Невскому, ранней осенью, на исходе дня. Впереди на вороном коне - скачок. С трубой у рта, как ангел Апокалипсиса» [ВодОЛАЗкин 2019: 32].

Описания, отражающие детское восприятие, характеризуются образами, в основе которых лежит остранение (В. Б. Шкловский), восприятие как бы «заново». При этом особенно часто используются образы, базирующиеся на анимизме, например: «У нас нет патефона, и я смотрю, как крутят ручку сидящие рядом. Кто сидит - не помню, но до сих пор вижу, как вращается ручка. Через мгновение раздается музыка - хриплая, заикающаяся, и всё же музыка. Пение. Ящик, полный маленьких, простуженных, поющих, - как же я тогда хотел им обладать!» [ВодолАзКин 2019: 36]

Прием остранения характерен и для описания взрослого состояния героя после размораживания: «Сегодня у меня сломался грифель, сказал об этом Валентине. Она из кармана достает что-то вроде карандаша, протягивает мне. Забавно, - говорю, -металлический грифель, никогда не видел такого» [ВодолАЗКин 2019: 18]. Этот тип восприятия отмечает и сам герой: «Таких неизвестно откуда всплывших фраз у меня уже несколько. У них есть, наверное, своя история, а я произношу их как в первый раз. Чувствую себя Адамом. Или ребенком: дети часто произносят фразы, еще не зная их смысла» [ВодоЛАзКин 2019: 22].

Образная оппозиция «ад / утраченный рай», отмеченная выше, входит в группу концептуализирующих образных параллелей. Если рай связан с детством, то метафора ада в романе неодномерна. Она используется, во-первых, для характеристики социально-политических условий: «Неужели, думалось, даже далекое будущее не выведет нас из большевистского ада?» [ВодоЛАЗКиН 2019: 244], во-вторых, для оценки внутреннего состояния персонажа: «А вообще, жизнь разваливается на части, хоть я и пытаюсь связать их воедино. Разваливается и прекращается. Держси ум твой во аде и не отчаивайся. Всё, о чем я ни думаю, погружает мой ум во ад. Который и есть отчаяние» [ВодОЛАЗКин 2019: 387]. 
С сюжетом романа непосредственно связаны также лексические единицы с семантикой 'холод'. Значение этих лексических единиц в тексте расширяется, приближаясь к метафорическому. Например, «Всё, что пишу сейчас, от волнения. От мерцающего моего сознания, не вполне еще, кажется, размороженного» [ВоДОЛАЗКИН 2019: 170], «Впрочем, и я, готовясь к погружению в азот, своих суждений уже не скрывал - от всех, не только от Муромцева. Мои слова доходили, скорее всего, до лагерного начальства, но оно относилось к ним совершенно спокойно. Знало, что все мои суждения будут заморожены вместе со мной. И никогда не растают» [ВодоЛАЗКИН 2019: 244].

Совмещение прямого и метафорического значения слова заморозить(ся) обыгрывается в каламбуре Гейгера: «Один из начальников паспортной службы оказался его бывшим пациентом. - До паспортной службы он тоже был заморожен? - спросила я у Гейгера. - Наоборот, - ответил Гейгер, - он заморозился, попав на службу. Но иногда оттаивает: вас распишут без очереди» [ВоДОЛАЗКИН 2019: 335].

Итак, к концептуализирующим группам компаративных тропов в романе относятся ключевые образные номинации главного героя (авиатор, Лазарь, Робинзон Крузо), метафоры памяти, образная оппозиция «ад / рай», тропы, связанные с воспоминаниями о детстве, и глагольные метафоры с семантикой холода.

К этой группе примыкает ряд компаративных тропов, отражающих отношения главного героя с возлюбленной со значащим именем Анастасия. Эти отношения характеризуются Платоновым метафорами воздушность, хруnкость: «Мы вот так же неподвижно лежали на кровати, рука в руке, висок к виску. Я тогда не мог сглотнуть слюну - боялся, что она услышит звук глотания, нарочно кашлял, чтобы оправдать этот звук - такими нематериальными были наши отношения. Или чтобы там хрустнуло в суставе - тоже боялся, потому что сразу разрушилась бы вся воздушность, вся хрупкость наших отношений. В них не было ничего телесного» [ВодолАзКин 2019: 30].

Описания возлюбленной строятся на оппозиции «Анастасия в прошлом / Анастасия в настоящем». В воспоминаниях Платонова употребляются такие сравнения и метафоры, как ноготь - чешуйка перламутра, волосы - шелк, пшеничный поток, рука - змейка. В описании же Анастасии в настоящем используются тропы с совсем другими образами сравнения: голос - скрип калитки, гвоздь по стеклу: «Вдруг Анастасия прерывает молчание. Она говорит: - Зарецкий. Это звучит как скрип калитки. Как гвоздь по стеклу. От нее тогдашней дальше всего ушла даже не внешность - голос» [ВодолАЗКин 2019: 209], в тексте возникает образ увядшего цветка. Растительная метафора, связанная с темой увядания, употреблялась в тексте и ранее: «Арбуз уже не так блестел, как тогда, в Сиверской, но ведь и время было другое. $<\ldots .>$ А еще я смотрел на Анастасию и думал, что вот, когда-нибудь она тоже увянет, что свежее, светящееся ее лицо сморщится, как арбузная корка. Может ли такое быть? И отвечал: не может» [ВодОЛАЗКИН 2019: 67]. 
Если первая группа тропов, которые носят в романе концептуализирующий характер, связана преимущественно с образами главного героя и Анастасии, то ко второй группе компаративных тропов относятся метафоры и сравнения, характеризующие других персонажей и окружающий их мир. Условно эти компаративные тропы можно назвать несюжетообразующими. В их составе прежде всего выделяются частотные в тексте зооморфные тропы. Так, в воспоминаниях Платонова о детстве животным уподобляются в основном предметы и растения. Это уподобление происходит на основе внешних впечатлений и непосредственных ощущений: паровоз - лошадь, личинка: «Остановившись в Сиверской, паровоз тяжело выдыхал, и это был его окончательный выдох. В нем еще что-то клокотало, шипело что-то, но готовности следовать дальше уже не было: в этих звуках проявляла себя лишь невозможность мгновенно затихнуть. Так после бега храпит, восстанавливая дыхание, скаковая лошадь» [ВодолАЗкин 2019: 43], «Поезд был виден издалека и подходил медленно. Как только он появлялся над точкой слияния рельсов, встречавшие поворачивались к нему лицом. Заметив, уже не выпускали из виду. Они еще говорили друг с другом, еще интересовались сиверскими новостями, но понастоящему внимание их было приковано к ползущей по рельсам личинке, к ее необъяснимому превращению в паровоз» [ВодолАЗКин 2019: 51], водоросли - змеи: «Сиверская, 1917-й, я стою, прислонившись к перилам мостика. Скрещенные на груди руки, взгляд, по просьбе отца, вдаль. Подо мною быстрое течение Оредежи, в струях воды извиваются водоросли. Если долго на них смотреть, кажется, что это речные змеи (есть такие?) плывут вверх по течению» [ВОДОЛАЗКИН 2019: 215], банки - маленькие злье рыбы, пираньи: «Новый прилив страха - перед снятием банок. Мальчику кажется, что в спину они впились намертво. Напоминают маленьких злых рыб. Может быть, пираний» [ВодОЛАЗКИН 2019: 366-367].

Зооморфные тропы в повествовании взрослого Платонова уже редко характеризуют внешние впечатления: «Под козырьком курили двое в белых халатах, тягуче сплевывали на землю. Два верблюда. Прошел мимо них к справочному окну» [ВодОЛАЗКин 2019: 169]. Чаще они имеют характер не непосредственного впечатления-уподобления, а характеризуют лиц, особенности их внутреннего мира, или же участвуют в обобщающих рассуждениях на социально-политические темы. Так, Аверьянов сопоставляется с крысой. Метафорический ряд, характеризующий Зарецкого, включает несколько образов сравнения, представляющих кластер «Насекомые и пресмыкающиеся»: червь, гнида, земноводное, рептилия: «Можно было бы сказать, что Зарецкий одинок, если бы это слово передавало происходящее с нашим соседом. Одинок ли в стволе древесный червь? А ведь было в нем что-то от червя. Гибкость, мягкость. Способность принимать температуру окружающей среды» [ВодОЛАЗКИН 2019: 6465], «Я подошел к двери Зарецкого и дернул за ручку. Она оказалась запертой изнутри на крючок. Я дернул ее двумя руками, и крючок слетел. Зарецкий сидел, сложив руки на столе. Стол был чист, на нем не было даже колбасы.

- Я убью тебя, гнида, - сказал я негромко. 
- Убъете пролетария - пойдете под суд, - так же негромко ответил Зарецкий. В его словах не было вызова, скорее - скорбь. Сидел неподвижно, и только на скуле дергался желвак. Земноводное. Скорбная рептилия» [ВоДОЛАЗКИН 2019: 106].

Этот образный ряд получает развитие и в речи Гейгера: Зарецкий - мокрища: «Этот рисунок потряс бы меня, даже если бы я ничего не знал о Зарецком. Но я ведь знаю - и рисунок потрясает вдвойне. Он освобождает Зарецкого. Избавляет от его страшной роли - быть мокрицей» [ВодОЛАЗКин 2019: 385].

Образы животных, как уже отмечалось, используются и в обобщающих рассуждениях героя на социально-политические темы: «Муромцев делал всё, чтобы продлить время нашего пребывания на Анзере, но что значили несколько подаренных недель в сравнении с отобранной жизнью? Мы чувствовали себя животныли, которых кормят на убой и которые - в отличие от обычных животных - об этом знают. Было в нашей жизни и в самом деле что-то животное - какое-то отупение было, не позволявшее приходить в отчаяние» [ВодОЛАЗКин 2019: 239].

Как отмечается в записях Гейгера, Платонов сравнивает население страны с глубоководными рыбами, которые могут жить только под давлением [ВОДОЛАЗКИН 2019: 328].

Современники Платонова, ставшие атеистами, сопоставляются им с божьей коровкой на шоссе: «Обилие открытий затуманило головы еще моим бывшим современникам, сделавшим атеизм модой. Уже тогда они напоминали божью коровку на шоссе. Она проползла десяток метров и очарована своим движением. Ей кажется, что она всё изучила и поняла. Но она никогда не узнает, где начинается шоссе и куда ведет» [ВОДолАзКИН 2019: 357].

Наряду с зооморфными тропами в тексте романа используются олицетворяющие (антропоморфные) тропы. Особенно часто они встречаются в описаниях природы: «И сосны, и волны меняют свой облик в сумраке белой ночи. В них появляется не то чтобы угроза, нет, просто они теряют свою дневную ласку. Так, видя улыбчивого человека задумавшимся, испытываешь беспокойство» [ВОДОЛАЗКИН 2019: 25].

Антропоморфные тропы отражают особенности детского восприятия, характеризующегося прежде всего установкой на конкретное, чувственное восприятие мира: «Путаясь в русских словах, финка хвалит свою корову. Эту корову я представляю похожею на саму молочнииу - огромной, неторопливой, с широко посаженными глазами и тугим выменем» [ВОДОЛАЗКИН 2019: 25]. С другой стороны, они передают точку зрения взрослого повествователя, в речи которого усложняется структура и семантика метафор и сравнений: «Слева тянулся ряд некрашеных гаражей, а справа - пустырь с посаженными по линейке чахлыми березками. Среди засохшей, со следами автомобильных колес, грязи эти березки не радовали глаз. Жизнь их была мучением. Их убогое кокетство было безотраднее ржавчины гаражей: те, по крайней мере, ни на что не претендовали» [ВодоЛАЗКИН 2019: 181]. 
Особую группу антропоморфных тропов в романе составляют олицетворения машин, механизмов, оборудования. Эти персонифицирующие метафоры и сравнения характерны для речи Платонова и Гейгера. Так, в записях Гейгера дается развернутая образная характеристика военных орудий: «Поднятые вверх стволы орудий. Темно-зеленые, постепенно возникают из серого. Задумчиво целятся в небо, блеск их матов. < .. > Царство неподвижного металла - и не дай Бог ему сдвинуться. < . .> Орудия потеряют свою задумчивость, может быть, даже просохнут. Будут без устали стрелять по цели и мимо» [ВодолАЗКИН 2019: 358-359]. В записях Платонова олицетворяется томограф: «Умная машина снимала мой мозг. Уж она, миленькая, увидит, отчего у меня подворачиваются ноги и отчего я стал забывчив. Всё доложит, спокойно и беспристрастно» [ВОДОЛАЗКИН 2019: 305].

В тексте романа используются и другие антропоморфные компаративные тропы, которые не входят в этом произведении в регулярно используемые кластеры. Это, например, метафорические предикаты, характеризующие смерть: «Нельзя сказать, что за своими жертвами смерть в наши бараки приходила: она в них жила. Ее присутствие стало настолько будничным, что на нее уже не обращали внимания. Умирали без страха» [ВодолАзКин 2019: 301], мысль: «Мысль уходила вбок, петляла. Норовила не вернуться к исходной точке» [ВодолАЗКин 2019: 110], душу: «Воронин сказал, что устал. Все решили, что это было сигналом к окончанию встречи. А я думаю, что он говорил о своем состоянии, когда нет уже ни злости, ни раскаяния. Душа погружается в сон» [ВодОЛАЗКИн 2019: 364].

Таким образом, для текста романа «Авиатор» характерна последовательная персонификация объектов изображаемого мира. Она распространяется на широкий круг описываемых реалий и явлений. Олицетворениию подвергаются как предметы материального мира, так и нематериальные сущности.

Реже встречаются в тексте образы сравнения других семантических классов. Так, метафоры и сравнения класса «Растения» характеризуют лиц: Был у меня знакомый, Алексей Константинович Аверьянов. Маленький, лысый, с большой головой, совершенный гриб. И размножался, видимо, спорами, потому что как же его такого можно представить с женщиной? <..> Кем он был, этот Аверьянов? Чем занимался, откуда я его знал - ничего не помню. А вот грибное его свойство, червивость эта, в памяти осталось» [ВодОЛАЗКИн 2019: 94], части тела: «Движение наше пусть не в Алушту, но в целом, кажется, на юг: в машине становится теплее. Опускаю стекло и кладу на окно локоть. Рука безвольна, силой ветра двигаются пальцы - вяло и меланхолично - как подводные растения» [ВОДОЛАЗКИН 2019: 208].

Компаративные тропы класса «Вода» характеризуют время: «Хочется, чтобы время замерло, как река у плотиныl» [ВодолАЗКИН 2019: 377-378], жизнь общества: «Я сейчас не могу как следует восстановить событий моей жизни, помню лишь, что, когда меня захлестыввали волны этого хаоса, спасала мысль о Петербурге - острове, о который они разбиваются...» [ВодОЛАЗкин 2019: 31], жизнь человека: «Сейчас, когда жизнь понемногу входит в русло, 
сквозь всё, что бы я ни делал, сквозь самую бытовую повседневность проступает счастье» [ВодоЛАЗКИН 2019: 227], мир звуков: «Чай осенью на открытой веранде. <..> Беседа - нескончаемые титаник да фердинанд - движется волнами, то тише, то громче» [ВоДоЛАЗКИН 2019: 364-365].

Непредметное в романе часто характеризуется как предметное, вещественное, например, сон: «Я лег на кровать и закрыл глаза. Мне захотелось исчезнуть, не быть, вновь замерзнуть и больше не оттаивать. Я провалился в сон, мутный и вязкий» [ВОДоЛАЗКИн 2019: 152]; слова: «В английском много таких словечек - маленьких, звонких, как шарик для пинг-понга, - удобных, в общем, и экономных» [ВОДОЛАЗКИН 2019: 139].

Отличительной особенностью романа «Авиатор» является соотнесенность компаративных тропов с нарративной структурой произведения. Различные субъектно-речевые планы характеризуются разными метафорами и сравнениями. Так, в речи Насти используются метафоры молодежного сленга: «Смотрела по телевизору репортаж из Кремля. Парни мои сегодня зажигали» [ВодолАзКин 2019: 272], в речи Гейгера - метафоры, связанные с научным дискурсом: «Рамки науки в нашем с Иннокентием случае тесны как никогда. Просто впиваются в ребра. Вдавливают в меня религиозную мысль, что помочь здесь может только Он» [ВОДОЛАЗКИн 2019: 357]. Тропы, закрепленные за разными субъектно-речевыми планами, могут вступать в оппозиции: если в воспоминаниях Платонова детство сопоставляется с раем, то для речи Насти характерно сравнение детского сада с зоной или армией: «Например, утреннее построение в детсаду - как на зоне или в армии. Полный скорби завтрак» [ВодолАЗКин 2019: 277].

Таким образом, в тексте романа Е. Водолазкина «Авиатор» широко представлены компаративные тропы разных типов. Объектами метафорического осмысления в романе чаще всего становятся главный герой произведения и связанные с ним понятийные сферы: «Детство», «Память», «Любовь». Ключевыми образными номинациями, характеризующими героя, служат обозначение профессии - авиатор - и прецедентные имена Лазарь, Робинзон Крузо. Эти прецедентные имена носят интертекстуальный характер и выявляют связи романа с библейским текстом и другими литературными произведениями. Ключевые образные номинации представляют собой ядро системы компаративных тропов и связаны с разными темпоральными планами произведения.

Как образы сравнения в тексте романа регулярно выступают названия животных, зооморфные тропы взаимодействуют в тексте с антропоморфными. Ведущим способом образного осмысления изображаемой действительности, имеющим глубокие когнитивные основания, выступает олицетворение.

Одновременно в тексте используются и тропы других семантических классов - «Растения», «Вода» и другие. Метафоры и сравнения в произведении не статичны, они регулярно отражают меняющееся во времени восприятие героя. Компаративные тропы взаимодействуют друг с другом и играют важную роль в развертывании ключевых мотивов романа. 
Совокупность метафорических моделей, реализуемых в тексте, образует систему компаративных тропов. Анализ метафорики романа способствует его интерпретации и выявляет особенности идиостиля писателя, а также позволяет определить некоторые особенности функционирования тропов в современной художественной прозе.

\section{Литература}

БАРАНОВ - электронный ресурс: Баранов, А.Н. Метафоры в романах А. Платонова «Чевенгур» и «Счастливая Москва. [электронный ресурс]. Доступно по адресу: https://www.lexrus.ru/inout/12-04-12055/metaph-Internet.pdf. Дата доступа: 02.08.2019.

ВодолАзкин 2019: Водолазкин, Е. Г. Авиатор: роман. Москва: Издательство АСТ: Редакция Елены Шубиной.

ГоловНЕВА-НовиковА 2018: Головнева, Ю. В., Новикова, А. А. Метафоры внутреннего мира человека в романе «Бесы» // Филологические науки. Вопросы теории и практики 3 (81). Ч. 1. Тамбов: Грамота 91-94.

ГУСЕВА 2018: Гусева, Д. В. Метафорические конструкции с номинациями вещей в русской прозе В. Набокова. Дисс. ... канд. филол. наук. Калининград.

ДмитРОВСКАЯ 2001: Дмитровская, М. А. От первой метафоры к последней: смысл финала романа В. Набокова «Машенька» // Текст. Интертекст. Культура. Сб. докладов международной научной конференции (Москва, 4-7 апреля 2001 г.). Москва: Азбуковник. 305-318.

КАДИМОВ-МАЛЛАЛИЕВ 2009: Кадимов, Р. Г., Маллалиев, Г. Н. Прием сравнения в поэтике повести Н. В. Гоголя «Тарас Бульба» // Известия Дагестанского гос. пед. унта. Общественные и гуманитарные науки 2. Махачкала. 50-54.

КЛЮчЕРОВА 2017: Ключерова, А. О. Структура и функции метафор в произведениях А. С. Грина. Дисс. ... канд. филол. наук. Москва.

КОжЕВНиКОВА 2009: Кожевникова, Н. А. Избранные работы по языку художественной литературы. Москва: Знак.

КожЕвниковА 2011: Кожевникова, Н. А. Стиль Чехова. Москва: Азбуковник.

ЛЕэмЕтс 1974: Леэметс, Х. Д. Метафора в русской романтической прозе 30-х годов XIX в. (на материале произведений А. А. Бестужева-Марлинского, Н. А. Полевого и В. Ф. Одоевского). Дисс. ... канд. филол. наук. Тарту.

МЕльниковА 2003: Мельникова, Е. М. Особенности функционирования метафоры в прозе О. Мандельштама // Ярославский педагогический вестник 1 (34). 53-55.

ОГольцЕВА 2010: Огольцева, Е. В. Пространство «Человека в футляре» и время «Ионыча» (сравнение в рассказах Чехова) // Преподаватель XXI век 1-2. Москва. 323-330.

Ружицкий 2015: Ружицкий, И. В. Язык Ф. М. Достоевского: Идиоглоссарий, тезаурус, эйдос. Москва: Лексрус.

Наталия НиколинА

Московский педагогический государственный университет

Россия, Москва

ruskafedra314@gmail.com

Зоя ПЕТРОВА

Институт русского языка им. В. В. Виноградова РАН

Россия, Москва

zoyap@mail.ru 